\title{
The Motion Analysis Technique of Flat Tennis Services
}

\author{
Akhmat Bagus Ajizi \\ Master Program in Sport Sciences \\ Universitas Negeri Yogyakarta \\ Yogyakarta, Indonesia \\ akhmatbagusazizi@gmail.com
}

\author{
Ria Lumintuarso \\ Faculty of Sport Sciences \\ Universitas Negeri Yogyakarta \\ Yogyakarta, Indonesia \\ loemin@yahoo.com
}

\begin{abstract}
- the purpose of this research is to know the: (1) engineering the right moves and disappear on a flat service tennis technique, (2) the Anthropometry of the ideal Athlete Tennis field matching using flat tennis court services. This research uses the mix method, which combines qualitative research and quantitative research in terms of methodology. The subject of the research in this study is SMES UNY tennis athletes who could do good flat services. There are several instruments in this research, including the Hewitt Service Placement Test, the assessment of the reference Norms (PAN), a test of Anthropometry (height, weight, height, arm length, scoring) and to measure the strength of the muscles of the arm use Dacin. Results showed that data: at the stage of preparation is good, very good product takeback on stage, at the stage of loading and hitting very well, at the stage of contact point very well, and on stage both follow through. From the results of the overall performance of the technique of servicing SME athletes performed flat tennis UNY 2018 categories very well. The ideal athlete on the Anthropometry that are suitable to use flat services should be: height $\geq 168 \mathrm{~cm}$, weight $\geq 58 \mathrm{~kg}$, height $\geq$ $210 \mathrm{~cm}$, arm length $\geq 71 \mathrm{~kg}$.
\end{abstract}

Keywords - service flat, tennis, anthropometry

\section{INTRODUCTION}

Indonesia's achievements in tennis looks like it declines, particularly on the number of players. We know, a couple of decades ago, Indonesia citizen, Yayuk basuki was a known figure in the mainstay of Indonesia's athletes in tennis, particularly as the Tennis Princess. Yayuk basuki was capable of achieving remarkable feats internationally. Her best achievement was when she was able to penetrate the world ranks and came $21^{\text {st }}$ in 1997 [6]. This was not an easy feat to attain. Unfortunately, this achievement has not been able to rub off on the young athletes now.

We know that the sport is starting to be on demand by the majority of the people of Indonesia. According to Maman, Chairman of PELTI suggests that, "throughout the year 2016 we've been rolling out eight ITF tournaments for senior and four for junior, while there are around 200 local tournaments" [7]. The growing number of people who are fond of playing tennis and the amount of coaching in different regions could not lift the achievements in Indonesia as good as Yayuk Basuki's era. As articulated by Mulyadi, "sports achievements in the Coaching tennis branch in sleman Regency in 2015, according to coaches and athletes were low $(25 \%)$." For that reason, the problem needs to be balanced with the right coaching, so it will be easier to attract the talented athlete seedlings. Good tennis training and coaching is required to create a many male and female achievers.

A tennis player needs to do the necessary preparations in training. They need to mature in their shot and also understand the capabilities and mastery of techniques, tactics, strategy, and can read the strength of the opponent. They should also be able to analyze where their own weakness lies. To be able to hit the ball, there are some basic techniques, namely: (a) a groundstroke that consists of forehand and backhand, (b) volley, also consists of forehand and backhand (c) service, (d) lob and smash [9].

In the game of tennis, players sometimes perform movements such as Sprint, sudden stops, then immediately move again, and do the step without ever losing balance of the body. The movements are performed repeatedly and in a steady tempo during a game. Due to the effect the movements will have on the body's joints, they need to rotate to perform action and reaction quickly in the game. Servicing the musculoskeletal injuries have the potential to Tennis because it is a recurring and do overhead movements while playing [5]. In a recent review, there are about 1000 per hour cuts 220 being played [8]. When in the execution of basic techniques is not proper tennis action reaction as well as the timing in his shot can result in the occurrence of injuries on joints or ligaments athletes.

In order to support the increased achievement in particular sports tennis is not separated from the process of coaching an athlete especially in terms of evaluating athletes by analyzing the movement of athletes using manual analysis of the coach or by the help of modern tools. This modern Diera, not many coaches want to evaluate athletes ' with detail. But there are a few basic techniques that should be dianaliasis with detail, in order to obtain the results of the basic techniques that are good and true.

Basic techniques that need to be evaluated early on is the basic techniques of servicing, it is because the basic engineering services is a basic technique to start the game of tennis courts. The service is a very important part, because the points will not be earned without doing advance services [4]. There are some technique services in the field of tennis, including the servicing of the Flat, servicing Slice, and service Twice.

Along with the development of techniques in the world of tennis sevis, the functionality of this service also increases. In addition to starting the game, the technical services may also be said to be the first attack techniques in the game of tennis. 
The elaboration of the technical service, the service that matches is used to gain points is the method the sevis flats, it is because the tekik service flats are very hard and fast. The service is the service that generates the ball straight and slid hard into the direction of the opponent's service box [10]. The results of the obsevasi has been done in the field, found that sevis flat often used in servicing first. It refers to the percentage chance of getting points higher than any other servicing techniques.

Based on the results of observation on the use of the services of the flat on the tennis courts in order to obtain initial points that had been made earlier, then the researchers want to do penelitain about "Motion Techniques Analysis Services Flat Tennis". The results of this analysis are expected to be useful as a material consideration in the preparation of training programs and methods of training the technique of playing tennis the right and true.

\section{METHODS}

\section{A. Research Method}

This research uses mix method, which combines quantitative and qualitative research in terms of methodology. This type of research combines qualitative research and quantitative research (such as in the stage of data collection) and the study of mixed model, combining approach in all stages of the research process [1].

\section{B. Research Setting}

This research was conducted at the tennis UNY in June 2018 at a time when the activities of the SME Tennis Team was precisely done on the UNY tennis court.

\section{Research Subjects}

In this study, the subject of the research was the athletes from UNY SME who can do technical flat servicing very well. From the research subjects, 8 people were taken as samples for this research.

\section{Data Gathering Technique and Instrument}

The instrument used in this study was in the form of the Hewitt Service Placement Test and a guide of reference Norms (PAN) that has been validated by experts and to supplement the data, researchers are also use for flat service speed sample. The assessment of the reference norms (PAN), flat service tennis techniques to assess movements, meter to obtain data of high scores and height, dacin to gain muscle strength and as a tool to make it easier to analyze flat service movement on athletes. Researchers also use Kinovea form Software computer to analyze movement techniques on the tennis court.

\section{E. Data Analysis Technique}

The method of data analysis in this study uses the help of the application Kinovea, for editing video that has been taken. Assessment of the results is done using the reference norms (PAN) as well as describing the results and calculating the values that have been obtained.
TABLE I. Norms Assessment ANAlysis of Flat SERVICE [2]

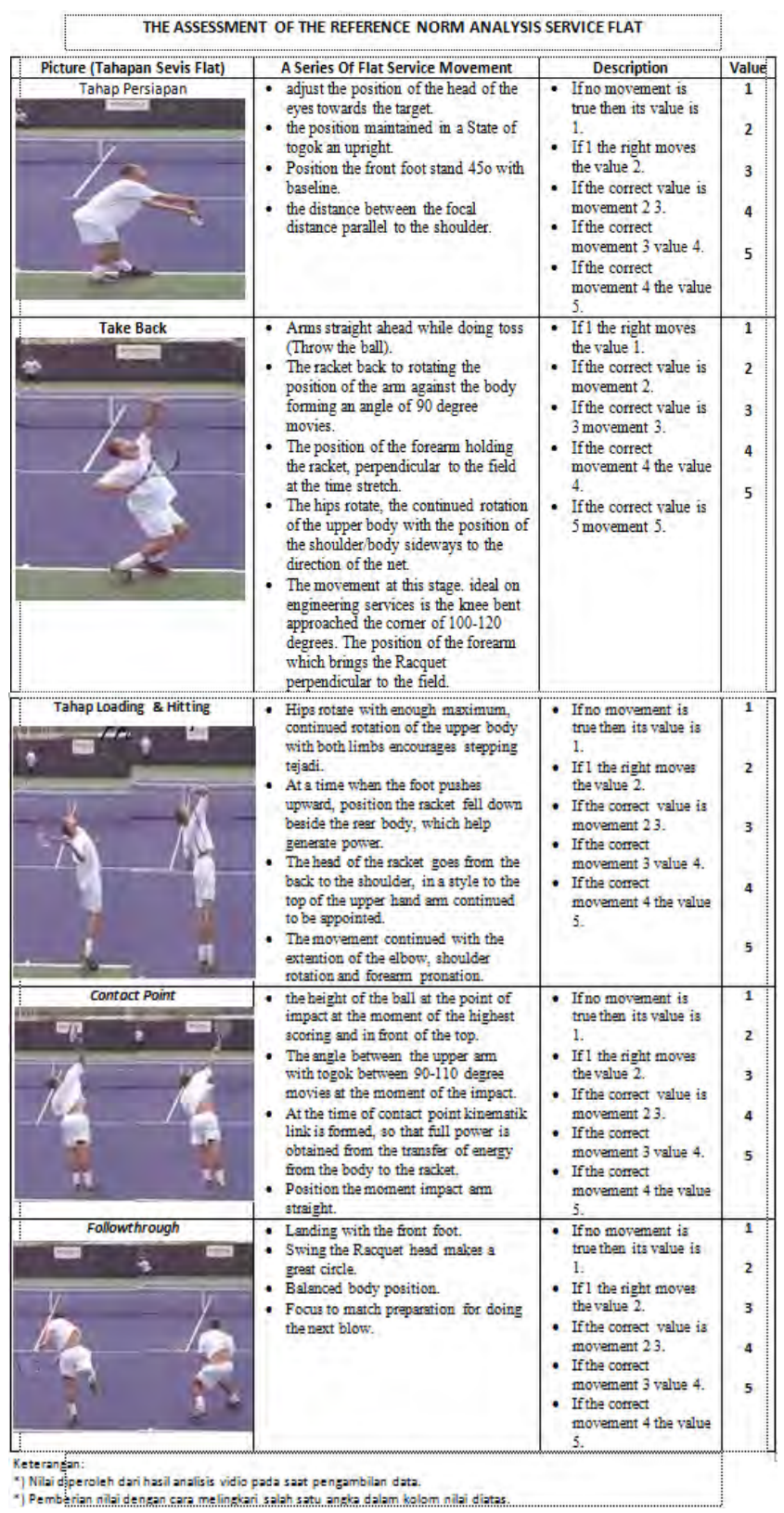

\section{RESULT AND DISCUSSION}

\section{A. Data Description}

The sample in this study involves several athletes from SME State University of Yogyakarta (UNY) that add up to 8 athletes. Out of the eight, researchers obtain various data required in completing the research. The data taken from the SME Tennis Athletes in the State University of Yogyakarta (UNY) include: Flat service performance, Anthropometry measurements (height, weight, arm length, the length of the series) and the measurement of muscle strength by using the tools in the form of Dacin.

In this study there were some data obtained from test instruments and measurements conducted on the sample. Such data include the following: the power of the arm muscles, Anthropometry (height, weight, arm length, high- 
Scoring), the speed of flat service on a tennis field, and the results of the Hewitt Service Placement Test.

The following descriptive results show research data presented in tabular form as follows:

TABLE II. SAMPLE DESCRIPTION

\begin{tabular}{|c|c|c|}
\hline No. & Name & Gender \\
\hline 1. & EM & Female \\
\hline 2. & NR & Female \\
\hline 3. & LDA & Female \\
\hline 4. & AA & Male \\
\hline 5. & PM & Male \\
\hline 6. & IM & Male \\
\hline 7. & GC & Male \\
\hline 8. & AN & Male \\
\hline
\end{tabular}

Table 2 explains that the whole sample in this research of eight SMES Tennis athletes in State University of Yogyakarta (UNY) consists of 3 females and 5 males.

While based on motion analysis and Assessment instrument Reference Norms (PAN) flat services have been validated by experts and the results of the datas hown as follows:

TABLE III. Flat SeRVices SPEed Data

\begin{tabular}{|c|c|c|c|r|}
\hline No. & Name & Distance (m) & Time (s) & Speed (m/s) \\
\hline 1. & EM & 18 & 0,55 & 32,73 \\
\hline 2. & NR & 18 & 0,53 & 33,96 \\
\hline 3. & LDA & 18 & 0,75 & 24 \\
\hline 4. & AA & 18 & 0,54 & 33,33 \\
\hline 5. & PM & 18 & 0,45 & 40 \\
\hline 6. & IM & 18 & 0,46 & 39,13 \\
\hline 7. & GC & 18 & 0,6 & 30 \\
\hline 8. & AN & 18 & 0,58 & 31,03 \\
\hline \multicolumn{5}{|c|}{ Rata-rata } \\
\hline
\end{tabular}

Table 3 explains that the average speed of flat services conducted by samples was 33.02 while the best value from the above data was 40.00 and the smallest value from the data above amounted to 24.00 .

TABLE IV. ARM Muscle StRENGTH DATA

\begin{tabular}{|l|l|c|c|}
\hline No. & \multicolumn{1}{|c|}{ Name } & $\begin{array}{c}\text { Arm muscle } \\
\text { strength (Kg) }\end{array}$ & Average \\
\hline 1. & EM & 7 & \multirow{2}{*}{} \\
\hline 2. & NR & 11 & \multirow{2}{*}{8,75} \\
\hline 3. & LDA & 7 & \\
\hline 4. & A.A & 10 & \\
\hline 5. & PM & 10 & \\
\hline 6. & IM & 6 & \\
\hline 7. & GC & 11 & \\
\hline 8. & AN & 8 & \\
\hline
\end{tabular}

Table 4 explains that the average strength of arm muscles performed by samples was 8.75 while the best value from the data above was 11 and the smallest value was 6 .
TABLE V. ANTHROPOMETRY DATA

\begin{tabular}{|l|l|c|c|c|c|}
\hline No. & Name & High Achierement (cm) & Arm Length (cm) & Hight (cm) & Weight (kg) \\
\hline 1. & EM & 201 & 70 & 162 & 80 \\
\hline 2. & NR & 208 & 72 & 167 & 61 \\
\hline 3. & LDA & 200 & 67 & 155 & 62 \\
\hline 4. & AA & 206 & 65 & 168 & 65 \\
\hline 5. & PM & 219 & 76 & 171 & 72 \\
\hline 6. & IM & 214 & 75 & 170 & 74 \\
\hline 7. & GC & 219 & 70 & 173 & 67 \\
\hline 8. & AN & 220 & 76 & 180 & 73 \\
\hline \multicolumn{2}{|c|}{ Rata-rata } & $\mathbf{2 1 0 , 8 7 5}$ & $\mathbf{7 1 , 3 7 5}$ & $\mathbf{1 6 8 , 2 5}$ & $\mathbf{6 9 , 2 5}$ \\
\hline
\end{tabular}

Table 5 explains that the average height of the team was 210.875 with the smallest value from the data above being 200 and the greatest value being 220. The average arm length in the table above was 71.375 while the smallest value was 65 and the greatest value, 76. From the above table we can also see an average of height and weight being 168.25 and 69.25 and the highest value of height and weight in the table being 80 and 180, while the lowest value of height and weight in the table was 155 and 61 .

TABLE VI. Hewitt Service Placement Test

\begin{tabular}{|c|c|c|c|c|c|c|c|c|c|c|c|c|c|}
\hline \multirow{2}{*}{ No. } & \multirow{2}{*}{ Name } & \multicolumn{10}{|c|}{ Serve } & \multirow[t]{2}{*}{$\Sigma$} & \multirow{2}{*}{ Grade } \\
\hline & & 1 & 2 & 3 & 4 & 5 & 6 & 7 & 8 & 9 & 10 & & \\
\hline 1. & EM & - & 2 & - & 4 & 6 & - & - & 3 & 2 & 5 & 22 & $\underline{\mathrm{C}}$ \\
\hline 2. & $\mathrm{NR}$ & 6 & 2 & 2 & - & - & 6 & 2 & - & - & 4 & 22 & $\underline{c}$ \\
\hline 3. & LDA & - & 2 & - & 4 & 3 & 3 & - & - & 4 & 2 & 18 & $\underline{\mathrm{D}}$ \\
\hline 4. & $\mathrm{AA}$ & 6 & - & 3 & - & 2 & 6 & - & 6 & - & 2 & 25 & $\underline{\mathrm{C}}$ \\
\hline 5. & PM & 4 & - & 6 & 4 & 2 & - & 3 & 6 & - & 2 & 27 & $\underline{c}$ \\
\hline 6. & $\mathrm{IM}$ & 4 & 4 & - & - & 6 & - & - & - & - & 6 & 20 & $\underline{\underline{c}}$ \\
\hline 7. & $\mathrm{GC}$ & - & 2 & - & - & 6 & - & 5 & 4 & 5 & - & 22 & $\underline{\mathrm{C}}$ \\
\hline 8. & AN & 4 & - & 2 & 2 & - & 3 & 6 & - & 6 & - & 23 & $\underline{\underline{c}}$ \\
\hline & & & & & & & & & & & & \begin{tabular}{|l|}
22,38 \\
\end{tabular} & \\
\hline
\end{tabular}

Table 6 explains that the average of the results of the Hewitt's tennis placement test conducted by the sample was 22.375 where 7 samples have a grade of $C$ and 1 sample had a grade D. The highest value from the data of Hewitt's tennis placement test above was 27 and the lowest value from the above data was 18 .

TABLE VII. ASSESSMENT OF REFERENCE NORM (PAN)

\begin{tabular}{|l|l|c|}
\hline \multicolumn{1}{|c|}{ No. } & \multicolumn{1}{|c|}{ Name } & $\begin{array}{c}\text { PAN's analysis } \\
\text { Result }\end{array}$ \\
\hline 1. & EM & 22 \\
\hline 2. & NR & 23 \\
\hline 3. & LDA & 21 \\
\hline 4. & AA & 22 \\
\hline 5. & PM & 24 \\
\hline 6. & IM & 23 \\
\hline 7. & GC & 24 \\
\hline 8. & AN & 23 \\
\hline \multicolumn{2}{|c|}{ Average } & $\mathbf{2 2 , 7 5}$ \\
\hline
\end{tabular}


Table 7 explains that the average results of analysis of the assessment of the reference norms (PAN) was 22.75 while the best value and smallest value were 24 and 21 .

\section{B. Discussion}

On technical services there are several stages to do in order to get good results, including the preparation phase, take back stage, the stage of loading and hitting, the contact point, and the last stage which is the followthrough [3]. From the stages, researchers have guidelines for analyzing the motion of flat service undertaken by the SME UNY 2018 tennis athletes. The guidelines that have been obtained are summarized and used as the assessment of the reference norms (PAN) which are then validated by the expert team. From the norm of reference assessment, the analysis results are as follows: (1) at the stage of preparation, the sample performs a series of movements of either category, (2) at the take back stage, the sample does a series of movements with excellent category, (3) At the stage of loading and hitting the sample performs a series of movements with excellent category, (4) On the stage of the contact point of the sample performs a series of movements with excellent category, (5) and in the followtrough sample performs a series of movements with either category. The overall performance of the technical flat service made by SME Team Tennis State University of Yogyakarta (UNY) can be categorized as very good, evident from the average obtained results of the assessment of the reference norms that indicate a value of 22.75. Once the average obtained from the results of the assessment of the reference norms (PAN) is found, then it will be linked to the results of other tests which includes tests of Anthropometry, tests the strength of arm muscle, and Hewitt Service Placement Test.

Hewitt Service Placement Test is used to find out how well servicing is done by tennis athletes [11]. From the test results obtained, the average results of samples was grade $\mathrm{C}$ and out of the 8 samples that did the tests, 7 samples obtained grade $\mathrm{C}$ and 1 sample obtained a grade D. With these results we can certainly see that the appropriateness of services obtained from the sample had a medium average. In addition, the Hewitt service placement test data also obtained avertage regarding the speed of service results flat conducted by SME Team Tennis of the State University of Yogyakarta (UNY).

Speed measuring results obtained from the manual uses the formula distance divided by time. The speed of the results of the services that have been performed by the samples showed an average $33.02 \mathrm{~m} / \mathrm{s}$. From the test results found, the fastest scoring values obtained a speed of $40.0 \mathrm{~m} / \mathrm{s}$ and a low speed of $24.0 \mathrm{~m} / \mathrm{s}$. The speed is obtained is as result of the influence of the strength of the muscles of the arm, because one of the factors that affect the speed of service is the strength of the muscles of the arm. Data from table 4 indicated that the highest arm muscles strength obtained by NR and GC was $11 \mathrm{~kg}$, whereas the lowest muscle strength acquired by the IM was $6 \mathrm{~kg}$.

Further data indicated by table 5 , describes 8 samples with Anthropometry data taken since last June. from these data it looks like the average high achievement was 210.875 $\mathrm{cm}$, arm length of $71.375 \mathrm{~cm}$, height of $168.25 \mathrm{~cm}$, and a weight of 69.25. As for the high scoring, the greatest value obtained was $220 \mathrm{~cm}$ and lowest obtained was $200 \mathrm{~cm}$. As for the length of the arm, the highest value obtained by the $\mathrm{PM}$ was $76 \mathrm{~cm}$ and lowest value obtained by AA was $65 \mathrm{~cm}$, For the height, the highest value obtained by AN was $180 \mathrm{~cm}$ and $155 \mathrm{~cm}$ for the lowest value, obtained by LDA. Next up was biggest weight obtained by EM with a weight of $80 \mathrm{~kg}$ and $61 \mathrm{~kg}$ for the smallest value obtained by NR.

Based on the above, the conclusion is that the movement needed to obtain good flat services is good precision accuracy, speed of service, then the Anthropometry. If the speed of servicing, accuracy and Anthropometry of the athletes are poor, then the results of the services will often not be right on target or not even cross the net. Furthermore, if the accuracy is good but the speed and Anthropometry bad, then it will be easy for the service to be returned by the opponent. Furthermore if Anthropometry is good and the speed and reliability poor, then the results will be that the services are returned and the balls will not cross the net.

With the data gotten, nice flat services will be done by athletes with the following conditions: height $\geq 168 \mathrm{~cm}$, weight $\geq 58 \mathrm{~kg}$, height $\geq 210 \mathrm{~cm}$, arm length $\geq 71 \mathrm{~kg}$. It can be seen from the top value and bottom value that appears in the previous analysis of data.

\section{CONCLUSION}

Based on the results of the research and the results of data analysis that has been done, the conclusion is that, at the stage of preparation it is good, very good product takeback on stage, at the stage of loading and hitting very well, at this stage of contact point very well, and on stage followthrough was good. From the results of the overall performance of technical servicing SME athletes performed flat tennis UNY 2018 categorized very well. For the ideal athlete the suitable Anthropometry to use flat services include: height $\geq 168 \mathrm{~cm}$, weight $\geq 58 \mathrm{~kg}$, height $\geq 210 \mathrm{~cm}$, arm length $\geq 71 \mathrm{~kg}$.

\section{REFERENCES}

[1] Abbas, T., and Charles T, Mixed Methodology; Mengombinasikan Pendekatan Kualitatif dan Kuantitatif. Yogyakarta: Pustaka Pelajar, 2010.

[2] Alim, A and Rismayanthi, C., "Analisis Biomekanik Tehnik Servis Pada Atlet Senior Diy. Yogyakarta," Journal UNY Saintek, 2011. (http://dx.doi.org/10.21831/jps.v16i1.1739).

[3] Alim, Abdul, "Analisis Gerak Tehnik Servis Tenis Lapangan," Jurnal, Yogyakarta: FIK UNY, 2010.

[4] Brown, Jim, Tenis Tingkat Pemula, Jakarta: Raja Grafindo Persada, 2001.

[5] Geoffrey D. A., etc, "Review of tennis serve motion analysis and the biomechanics of three serve types with implications for injury," Sports $\begin{array}{llll}\text { Biomechanics, } 10: 4, & 378-390, & 2011 . & \text { DOI: }\end{array}$ 10.1080/14763141.2011.629302

[6] http://www.itftennis.com (Diakses pada 7 juni 2017)

[7] https://sport.detik.com/raket/d-3396570/bertemu-presiden-itf-pelticurhat-soal-tenis-indonesia.

[8] Kibler,W.B., Safran M., "Tennis Injuries, Epidemiology of Pediatric Sports Injuries," Individual Sports. Med Sport Sci. Basel, Kargervol, 2005, 48, pp 120-137,

[9] Nugroho, Untung, "Analisis Biomekanika Forehand Groundstroke Tenis Lapangan Atlet Yunior Daerah Istimewa Yogyakarta," S2 Thesis, Universitas Negeri Yogyakarta, 2012.

[10] Schraff, Robert, "Bimbingan Main Tenis Cepat dan Mudah," Jakarta: Mutiara, 2001.

[11] Strand, B. and Wilson R., Assessing Sport Skills, Human Kinetics Publisher, 1993. 